\title{
Monoclonal antibodies for detecting bone marrow invasion by neuroblastoma
}

\author{
D W ROGERS, J G TRELEAVEN,* J T KEMSHEAD,* J PRITCHARD the Department of \\ Haematology and Oncology, The Hospitals for Sick Children, and the *Imperial Cancer Research Fund \\ Oncology Laboratory, Institute of Child Health, London
}

SUMMARY One hundred and sixty six bone marrow aspirates from children with abdominal neuroblastoma were independently examined for the presence of neuroblastoma cells by conventional haematological staining techniques and by indirect immunofluorescence using one or more of five monoclonal antibodies. Results using the two methods were evaluated by comparison with the results of bone marrow, bone and lymph node biopsy specimens taken at the same time, and in the light of the child's clinical course. One antibody, UJ13A, was found to have $98.5 \%$ specificity and $85.7 \%$ sensitivity, compared with sensitivities for conventional staining of $50 \%$ for aspirate alone and of aspirate or trephine biopsy specimen of $71.4 \%$. The remaining antibodies UJ127/11, UJ223/8, UJ181/4 and UJ167/11, with specificities in the range 94-99\%, were found to have sensitivities in the range $47-61 \%$, lower than the sensitivity of conventionally stained aspirate or trephine biopsy specimen. Routine immunofluorescence staining with monoclonal antibody UJ13A should increase the sensitivity of detection of metastatic neuroblastoma.

Detection of bone marrow infiltration is of clinical importance in the management of children with neuroblastoma for the following reasons:

(i) at diagnosis to determine stage of disease and hence treatment and prognosis; (ii) during treatment to assess response; (iii) before marrow harvest for autologous marrow rescue; (iv) after completion of treatment to confirm or refute suspected relapse.

The focal pattern of infiltration often shown by neuroblastoma and the morphological similarity of neuroblastoma cells to normal lymphoid cells make it difficult to diagnose minor degrees of infiltration by conventional cytological and histological techniques. ${ }^{12}$ Mouse monoclonal antibodies raised against human fetal brain cells can be selected to distinguish between neuroblastoma cells and cells of lymphoid origin. ${ }^{3}$ Their use in showing the neuroectodermal origin of unequivocally "foreign" cells detected in bone marrow by conventional staining is now generally accepted, ${ }^{4}$ but the clinical importance of detecting antibody positive cells in the absence of morphological evidence of infiltration is still debated. We therefore reviewed our experience of immunofluorescence staining to see whether this method is a more sensitive way of detecting bone marrow infiltration than conventional staining.

As no independent criteria for assessing bone

Accepted for publication 19 October 1988 marrow infiltration exist three assumptions were made before calculating sensitivities and specificities for the different methods. Firstly, when aspirates or biopsy specimens at other sites unequivocally showed disseminated disease by conventional staining, the immunological detection of antibody positive cells in marrow apparently free of tumour was considered to indicate infiltration. Secondly, persistence of antibody positive cells after only two courses of chemotherapy was interpreted as persistence of such infiltration. Thirdly, the clinical outcome, as judged by four year disease-free survival, was regarded as the ultimate confirmation that marrow was tumour free after treatment.

\section{Patients and methods}

Between January 1980 and December 198131 children resident in the United Kingdom were referred to the Hospital for Sick Children with abdominal neuroblastoma at first diagnosis. Diagnostic criteria have been defined previously. ${ }^{5}$ Results of bone marrow aspirates examined by both conventional and monoclonal antibody methods were available for 23 of these children. Details of age, sex and stage ${ }^{6}$ at diagnosis are given in table 1 .

Bilateral bone marrow iliac crest aspirations and trephine biopsies were performed routinely on all children at diagnosis and thereafter in children with 
Table 1 Presentation and outcome of children studied

\begin{tabular}{|c|c|c|c|c|c|}
\hline Case No & Sex & $\begin{array}{l}\text { Age } \\
\text { (months) }\end{array}$ & $\begin{array}{l}\text { Stage } \\
\left(\text { Evans }^{6}\right)\end{array}$ & Metastases & Outcome \\
\hline $\begin{array}{r}1 \\
2 \\
3 \\
4 \\
5 \\
6 \\
7 \\
8 \\
9 \\
10 \\
11 \\
12 \\
13 \\
14 \\
15 \\
16 \\
17 \\
18 \\
19 \\
20 \\
21 \\
22 \\
23\end{array}$ & $\begin{array}{l}\mathbf{M} \\
\mathbf{M} \\
\mathbf{M} \\
\mathbf{M} \\
\mathbf{M} \\
\mathbf{F} \\
\mathbf{M} \\
\mathbf{M} \\
\mathbf{M} \\
\mathbf{F} \\
\mathbf{F} \\
\mathbf{F} \\
\mathbf{M} \\
\mathbf{F} \\
\mathbf{M} \\
\mathbf{F} \\
\mathbf{M} \\
\mathbf{F} \\
\mathbf{M} \\
\mathbf{F} \\
\mathbf{M} \\
\mathbf{M} \\
\mathbf{M}\end{array}$ & $\begin{array}{l}0 \\
2 \\
5 \\
6 \\
6 \\
8 \\
15 \\
18 \\
19 \\
19 \\
31 \\
34 \\
37 \\
44 \\
47 \\
53 \\
55 \\
56 \\
58 \\
59 \\
65 \\
70 \\
77\end{array}$ & $\begin{array}{l}\text { III } \\
\text { I } \\
\text { IVs } \\
\text { IV } \\
\text { IV } \\
\text { IV } \\
\text { IV } \\
\text { III } \\
\text { III } \\
\text { III } \\
\text { IV } \\
\text { IV } \\
\text { IV } \\
\text { IV } \\
\text { IV } \\
\text { IV } \\
\text { IV } \\
\text { IV } \\
\text { IV } \\
\text { IVs } \\
\text { IV } \\
\text { IV } \\
\text { IV }\end{array}$ & $\begin{array}{l}\text { Lymph node } \\
\text { Marrow, liver, later orbit } \\
\text { Marrow, bone, liver } \\
\text { Liver } \\
\text { Marrow, orbit } \\
\text { Marrow, bone, lymph node } \\
\\
\text { Lymph node } \\
\text { Marrow } \\
\text { Marrow, bone, lymph node } \\
\text { Marrow, bone, lymph node } \\
\text { Marrow, bone } \\
\text { Marrow, bone } \\
\text { Marrow, bone } \\
\text { Marrow, bone, lymph node, liver } \\
\text { Marrow, bone, lymph node } \\
\text { Liver } \\
\text { Marrow, bone } \\
\text { Marrow, bone, lymph node } \\
\text { Marrow, bone }\end{array}$ & $\begin{array}{l}\text { Alive no evidence of disease } \\
\text { Alive no evidence of disease } \\
\text { Alive no evidence of disease } \\
\text { Alive no evidence of disease } \\
\text { Alive no evidence of disease } \\
\text { Alive no evidence of disease } \\
\text { Alive no evidence of disease } \\
\text { Alive no evidence of disease } \\
\text { Died } 12 \text { months } \\
\text { Died } 5 \text { months } \\
\text { Alive no evidence of disease } \\
\text { Died } 12 \text { months } \\
\text { Died } 12 \text { months } \\
\text { Alive no evidence of disease } \\
\text { Alive no evidence of disease } \\
\text { Alive no evidence of disease } \\
\text { Died } 28 \text { months } \\
\text { Died } 9 \text { months } \\
\text { Died } 31 \text { months } \\
\text { Alive with disease } \\
\text { Died } 2 \text { days } \\
\text { Alive no evidence of disease } \\
\text { Died } 16 \text { months }\end{array}$ \\
\hline
\end{tabular}

initially diseased marrows after every two courses of treatment. Before bone marrow harvest aspirations were performed from all four iliac spines to confirm absence of infiltration. Children surviving stage III or IV disease underwent four monthly marrow sampling for two years after completion of treatment.

As part of the routine assessment of each bone marrow aspirate spread films of aspirated material were stained with May-Grünwald-Giemsa and were examined for the presence of tumour cells using light microscopy by an experienced haematologist. As the aim of the study was to establish the additional contribution that might be made to our routine practice by monoclonal antibody studies no additional blind review was performed for purposes of the study; similarly, trephine biopsy specimens were examined by an experienced histopathologist according to routine procedures but without further blind review.

For monoclonal antibody studies, $0.2-0.5 \mathrm{ml}$ of aspirate were added to $5 \mathrm{ml}$ of tissue culture medium (Roswell Park Memorial Institute) containing $0.5 \mathrm{ml}$ of $1 / 1000$ preservative-free heparin. Nucleated cells were separated by layering the sample onto $5 \mathrm{ml}$ Ficoll and centrifuging at $150 \mathrm{~g}$ for 10 minutes. Cells were counted using a Neubauer counting chamber, and $1 \times 10^{6}$ nucleated cells were incubated with each individual monoclonal antibody in an LP3 tube. The number of antibodies used to test the cells therefore depended on the total cell count.

The panel of antibodies used included the following antibodies known to be sensitive to neuroectodermally derived tissue: UJ13A, ${ }^{7} \mathrm{UJ} 127 / 11,{ }^{8} \mathrm{UJ} 223 / 8,{ }^{3} \mathrm{UJ} 181 /$ $4^{3}$ and UJ167/11. ${ }^{3}$ UJ308, which recognises normal myeloid precursor cells, was used as a positive control.
Sufficient antibody was added to $1 \times 10^{6}$ nucleated cells to saturate all potential binding sites on tumour cells (assuming 100\% infiltration). Samples were incubated at room temperature for 30 minutes and then washed twice using $0.9 \%$ saline $/ 10 \%$ fetal calf serum. Twenty microlitres of fluoresceinated sheep anti-mouse immunoglobulin were added and the samples incubated for a further 30 minutes at room temperature. They were then washed twice with physiological saline $/ 10 \%$ fetal calf serum to which $1 \%$ azide had been added.

Cells were mounted wet on glass microscope slides, sealed under coverslips using wax, and inspected under ultraviolet light using a Zeiss fluorescence microscope with epi-illumination. A minimum of 10 fields were inspected using $\times 630$ magnification. Tumour cells were identified either as clumps or single cells outlined with fluorescence, a single fluorescent clump or cell being regarded as a positive result.

During the study clinicians used the results of conventional and histological examination but not of immunofluorescence when assessing marrow infiltration and hence disease stage, response, or relapse. Immunofluorescence results did not therefore influence clinical management of the children.

For retrospective assessment of the antibody method, results for each antibody were compared with the reported results of conventional examination of spread films of material from the same aspiration. When the results of all antibodies used agreed with the results of conventional staining the result for each antibody was classified as true positive or true negative. When there was disagreement between the conventional results and one or more antibody results 
Table 2 Aspirates reported positive for conventional staining or immunofluorescence

\begin{tabular}{|c|c|c|c|c|c|c|c|c|}
\hline \multirow[b]{2}{*}{ Case No } & \multirow[b]{2}{*}{ Disease } & \multirow[b]{2}{*}{ Aspirates } & \multirow[b]{2}{*}{ Trephines } & \multicolumn{5}{|c|}{ Antibodies } \\
\hline & & & & $13 A$ & $127 / 11$ & $223 / 8$ & $181 / 4$ & $167 / 11$ \\
\hline \multirow[t]{2}{*}{4} & Diagnosis & + & + & - & - & - & - & - \\
\hline & Diagnosis & + & + & - & - & - & - & - \\
\hline \multirow[t]{2}{*}{7} & Treatment ${ }^{*}$ & - & ND & + & ND & ND & ND & ND \\
\hline & Treatment ${ }^{*}$ & - & ND & + & ND & ND & ND & ND \\
\hline \multirow[t]{2}{*}{9} & Relapse & + & ND & + & - & - & - & - \\
\hline & Relapse & + & ND & + & ND & ND & ND & ND \\
\hline \multirow[t]{4}{*}{11} & Diagnosis† & - & - & + & + & + & + & + \\
\hline & Diagnosis $\dagger$ & - & - & + & + & + & + & + \\
\hline & Treatment* & - & - & + & + & + & + & + \\
\hline & Treatment* & - & - & + & + & - & - & - \\
\hline 12 & Diagnosis & + & ND & - & - & - & - & - \\
\hline \multirow[t]{2}{*}{15} & Diagnosis & + & ND & + & + & + & + & - \\
\hline & Diagnosis & + & ND & + & + & + & - & - \\
\hline 16 & Diagnosis & + & + & + & + & + & + & + \\
\hline \multirow{2}{*}{17} & Relapse & + & ND & + & + & ND & + & + \\
\hline & Relapse & + & ND & + & + & ND & - & + \\
\hline \multirow[t]{2}{*}{18} & Relapse $†$ & - & ND & + & ND & ND & ND & ND \\
\hline & Relapse $†$ & - & ND & + & ND & ND & ND & ND \\
\hline \multirow[t]{5}{*}{19} & Diagnosis & + & + & + & ND & ND & ND & ND \\
\hline & Diagnosis & - & + & ND & ND & ND & ND & ND \\
\hline & Relapse 1 & + & + & + & - & ND & - & + \\
\hline & Relapse 1 & - & + & + & - & ND & - & + \\
\hline & Relapse 2 & + & + & + & + & ND & ND & ND \\
\hline \multirow{5}{*}{22} & Diagnosis & + & ND & + & ND & ND & ND & ND \\
\hline & Treatment & - & + & + & ND & ND & ND & ND \\
\hline & Treatment & - & + & - & ND & ND & ND & ND \\
\hline & Treatment & - & + & + & + & ND & ND & - \\
\hline & Treatment & - & + & + & - & + & ND & - \\
\hline
\end{tabular}

* Only two courses of treatment after evidence of disseminated disease by conventional staining.

†Biopsy (node/bone) positive at another site by conventional staining.

the individual antibody result was assessed in relation to the results of trephine, lymph node, and bone biopsy specimens and in relation to clinical outcome as follows.

Positive antibody results with negative conventional results were classified as true positive if there was evidence from aspirate or trephine biopsy specimen of marrow disease at another site or evidence from lymph node or bone histology of disseminated disease. They were also classified as true positive if positive in children with disseminated disease (shown by conventional techniques at diagnosis) who had received only two courses of chemotherapy. They were classified as false positive if occurring in children off treatment without any other evidence of disease who sub-

Table 3 Aspirates reported positive by immunofluorescence in children off treatment who have remained clinically free of disease

\begin{tabular}{lllllllll}
\hline \multirow{7}{*}{$\begin{array}{llllll}\text { Case } \\
\text { No }\end{array}$} & Aspirates & Trephines & $13 A$ & $127 / 11$ & $223 / 8$ & $181 / 4$ & $167 / 11$ \\
\hline 6 & - & - & + & + & + & + & + \\
14 & - & - & - & - & - & - & + \\
22 & - & - & - & - & - & ND & + \\
& - & - & + & - & - & - & + \\
\hline
\end{tabular}

sequently remained in continuous remission for at least three years without any further treatment. Negative antibody results were classified as false negative if material from the same aspirate was reported as unequivocally positive with definite identification of tumour cells using conventional staining.

Sensitivity was calculated as the number of true positive results divided by the sum of true positive and false negative results. Specificity was calculated as the number of true negative results divided by the sum of true negative and false positive results.

\section{Results}

Because of the demands of clinical work not all aspirates were taken at times suitable for antibody analysis and because of difficulties in obtaining an adequate sample ${ }^{1}$ not all specimens submitted were suitable for analysis or could be tested with the full panel of antibodies. Twenty three children, however, had simultaneous cytological and immunological marrow examinations on at least one occasion giving a total number of 166 paired assessments, of which 28 fulfilled the criteria for conventional or immunofluorescence true positive results (table 2), and five fulfilled the criteria for antibody false positive results (table 3). The remaining 133 results were considered to 
Table 4 Sensitivity and specificity of monoclonal antibodies

\begin{tabular}{llllllc}
\hline Antibody & True positive & False negative & False positive & True negative & Percentage sensitivity & Percentage specificity \\
\hline UJ13A & 24 & 4 & 2 & 135 & $85 \cdot 7$ & $98 \cdot 5$ \\
UJ127/11 & 11 & 7 & 1 & 102 & $61 \cdot 1$ & $99 \cdot 0$ \\
UJ223/8 & 7 & 5 & 1 & 80 & $58 \cdot 3$ & $98 \cdot 8$ \\
UJ181/11 & 6 & 9 & 1 & 77 & $40 \cdot 0$ & $94 \cdot 0$ \\
UJ167/11 & 8 & 9 & 5 & 0 & 78 & 100 \\
Aspirates & 14 & 14 & 0 & 135 & $71 \cdot 4$ & 100 \\
$\begin{array}{l}\text { Aspirates } \\
\text { or trephines }\end{array}$ & 20 & 8 & & 0 & $50 \cdot 0$ & \\
\hline
\end{tabular}

be true negative for both conventional staining and immunofluorescence. Table 4 shows the results obtained for conventional staining and for each antibody together with individual sensitivities and specificities.

\section{Discussion}

Favrot et al showed that in some patients with neuroblastoma bone marrow aspirates were positive by antibody testing in the absence of other evidence of marrow disease. ${ }^{4}$ In six of these patients this antibody positivity correlated with subsequent relapse despite treatment: in the remaining four insufficient follow up information was available for assessment.

If in the absence of evidence of marrow infiltration by conventional examination of marrow aspirate and marrow biopsy specimen antibody positivity is to be accepted as evidence in its own right of marrow infiltration, the antibody must show a high specificity for neuroblastoma cells. If such evidence is to be useful to the clinician the sensitivity of the antibody method must be at least as great as that of conventional methods. This retrospective study suggests that one antibody in particular, UJ13A, in addition to showing a high specificity for neuroblastoma cells in bone marrow, may also have a sensitivity greater than conventional morphological methods. In this study assessment was based on the presence or absence of other evidence of disseminated disease and on clinical outcome, but in future studies it may be possible to compare the antibody results with those of neurone specific enolase staining, ${ }^{9}$ in situ hybridisation for $N$-myc amplification, ${ }^{10}$ or of cell culture techniques. ${ }^{11}$

The remaining four antibodies used in this study showed good specificity for neuroblastoma cells but less sensitivity than either conventional staining or UJ13A. This lesser sensitivity might relate to variation of antigen expression in different neuroblastomas, as suggested by the varying patterns of antibody positivity shown by the tumours themselves. ${ }^{12}$ Although the numbers of observations from which the sensitivities of these antibodies were calculated were small, the results suggest that use of a panel of antibodies, our current practice, ${ }^{3}$ increases the specificity of detection by this method but not the sensitivity. The importance of this observation varies with the particular context in which the marrow is being examined: thus at initial diagnosis or at diagnosis of relapse a high level of specificity is desirable while in the assessment of response and particularly before marrow harvest a high level of sensitivity is more important.

We conclude that monoclonal antibodies have increased our ability to detect and characterise neuroblastoma cells in bone marrow and that their use can improve staging and management of this disease.

We acknowledge the support of the Imperial Cancer Research Fund and the Leukaemia Research Fund and thank all our clinical and laboratory colleagues whose care of and for the children made this study possible.

\section{References}

1 Franklin IM, Pritchard J. The detection of bone marrow invasion by neuroblastoma is improved by sampling at two sites with both aspirate and trephine biopsy. J Clin Pathol 1983;36: 1215-8.

2 Hann IM, Rankin A, Lake BD, Pritchard J. Colour atlas of paediatric haematology. Oxford: Oxford University Press, 1983;92-4.

3 Kemshead JT, Goldman A, Fritschy J, Malpas JS, Pritchard J. Use of panels of monoclonal antibodies in the differential diagnosis of neuroblastoma and lymphoblastic disorders. Lancet 1983; i:12-4.

4 Favrot MC, Frappaz D, Maritaz O, et al. Histological, cytological and immunological analyses are complementary for the detection of neuroblastoma cells in bone marrow. $\mathrm{Br} J$ Cancer 1986;54:637-41.

5 Shafford EA, Rogers DW, Pritchard J. Advanced neuroblastoma: improved response rate using a multiagent regimen (OPEC) including sequential cisplatin and VM-26. J Clin Oncol 1984:2:742-7.

6 Evans AE, D'Angio GJ, Randolph J. A proposed staging for children with neuroblastoma. Cancer 1971;27:374-8.

7 Allan PM, Garson JA, Harper EI, et al. Biological characterization and clinical applications of a monoclonal antibody recognizing an antigen restricted to neuroectodermal tissues. Int J Cancer 1983;31:591-8.

8 Kemshead JT, Fritschy J, Garson JA, et al. Monoclonal antibody 
ÚJ127:11 detects a $220,000-240,000$ kdal glycoprotein present on a sub-set of neuroectodermally derived cells. Int $J$ Cancer 1983;31:187-95.

9 Tsokos M, Linnoila RI, Chandra RS, Triche TJ. Neuron-specific enolase in the diagnosis of neuroblastoma and other small. round cell tumors in children. Hum Pathol 1984;15:575-84.

10 Garson JA, Van den Berghe JA, Kemshead JT. High-resolution in situ hybridization technique using biotinylated $n$-myc oncogene probe reveals periodic structure of HSRs in human neuroblastoma. Cytogenet Cell Genet 1987;45:10-5.

11 Joshi SS, Kessinger A, Mann SL, et al. Detection of malignant cells in histologically normal bone marrow using culture techniques.
Bone Marrow Transplantation 1987:1:303-10.

12 Oppedal BR, Brandtzaeg P. Kemshead JT. Immunohistochemic:al performance testing of monoclonal antibodies to neuroblastoma cells on normal adrenals, spinal and sympathetic ganglia, and neural crest tumours. Histopathology 1987:11: $351-62$.

Requests for reprints to: Dr J Pritchard, The Hospital for Sick Children, Great Ormond Street. London WCIN 3JH, England.

व)

它

$\omega$

종

N

$+$

N 